풀 “The authors on this paper have apparently never published a single academic paper before and they list a non-academic e-mail address," he wrote. "Odder still, upon looking for them on Google, PubMed or on the website of the university they list, there is no mention of any of the authors as being at that university."

Carafoli, along with Elsevier, launched an investigation. Elsevier temporarily withdrew the paper from the journal website on 8 August, and, after the University of Thessaly confirmed that none of the researchers listed on the paper had ever worked there, now intends to withdraw it permanently.

Spiegelman, who works on fat-cell differentiation, is also a co-founder of Ember Therapeutics, a company based in Watertown, Massachusetts, that is developing therapeutics for metabolic disorders. He believes that the paper was intended to hurt him and his lab. Scientific misconduct is usually done for academic gain, but because the authors on the paper seem to be phantoms, they can derive no benefit, he says. He argues that this seems to leave "maliciousness" as the only explanation.

Spiegelman says that he is surprised that the e-mail address of the corresponding author did not prompt the journal to ask for evidence of the authors' institutional affiliations. "The e-mail was a bit strange, and that we could have checked," agrees Carafoli, but nothing else in the paper aroused suspicion. "It was impeccable. The authors were clearly academics," he adds.

The perpetrators also seem to have used Greek surnames similar to those of authentic researchers working in obesity-related research, in what one might speculate was an attempt to fool referees should they search the literature. There are also genuine researchers at the University of Thessaly working in the field of obesity.

Spiegelman, who is certain that the paper is "made up", is keen for there to be a criminal investigation. He says that lawyers have told him that the faked paper represents fraud, not just academic misconduct - a view shared by Carafoli. But Spiegelman says the lawyers also advised that although he might have been the target, there would be little basis for him to sue, whereas Elsevier, $B B R C$ and the University of Thessaly could have grounds to press fraud charges.

Elsevier told Nature: "BBRC has been targeted by a scheme to defraud our editors, reviewers and readers with submission of a manuscript with falsified author and institutional information and therefore wholly unverifiable scientific claims. We consider such abuse unethical." It added that it is continuing its investigation and will, with the relevant authorities, "explore the question of whether this constitutes a criminal case of Internet fraud".
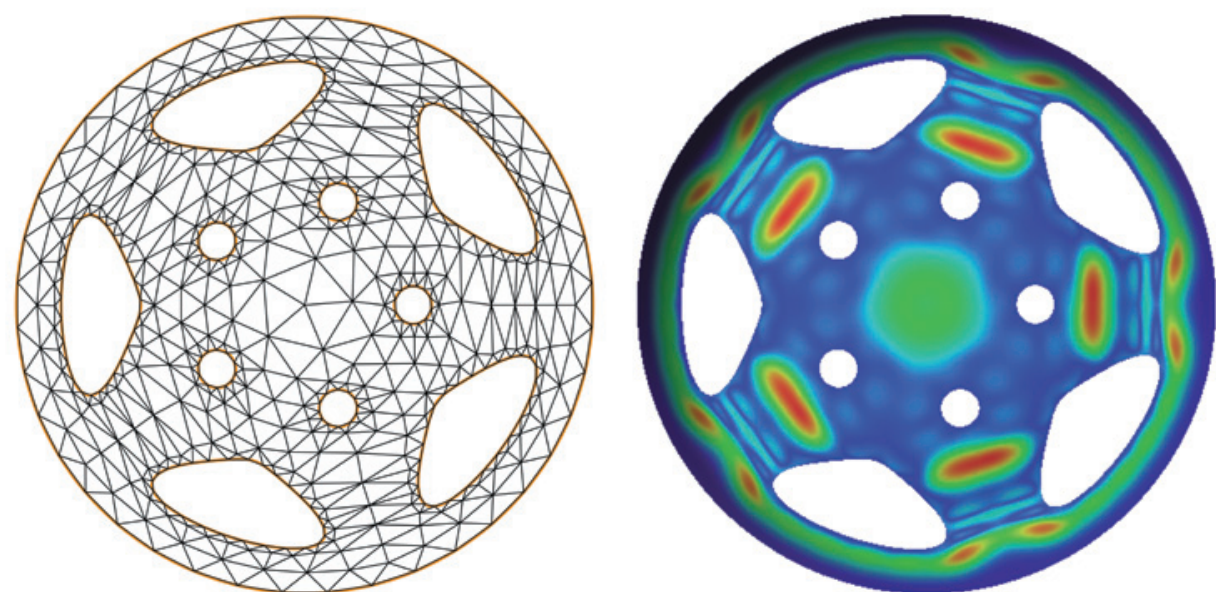

A surface imaged by a patented method that was licensed to Intellectual Ventures by Caltech.

TECHNOLOGY TRANSFER

\title{
Universities struggle to make patents pay
}

\section{Surfeit of unlicensed intellectual property pushes research institutions into unseemly partnerships.}

\section{BY HEIDI LEDFORD}

$\mathrm{U}$ nited States patent number 7,023,435 almost didn't happen. The application, which covered a way of imaging a surface, was rejected four times by the US Patent and Trademark Office. But the California Institute of Technology (Caltech) in Pasadena, which filed the patent, fought back - and prevailed in 2005

Caltech's faith in the hard-won patent was not matched by industry: three years later, no one had licensed the rights to the invention. So in 2008, Caltech exclusively licensed it, along with 50 other patents, to a subsidiary of Intellectual Ventures, a company that has stockpiled 40,000 patents from which it collects US $\$ 3$ billion in licensing income. The firm sometimes uses its patents to sue other companies for infringement, yet it rarely develops the inventions described by its intellectual property.

Such patent-assertion entities, sometimes called aggregators, monetizers or 'patent trolls', are questionable homes for university inventions. But in the push to get academic research out of the ivory tower - and to make money - university technology-transfer offices are becoming less choosy about their partners.

"As universities struggle to find revenue sources, one might worry that the monetization industry will be very tempting," says Robin Feldman, director of the Institute for Innovation Law at the University of California Hastings College of the Law in San Francisco.

There are already signs that this is happening, she adds. Last year, she published evidence that 45 universities around the world licensed or sold patents to Intellectual Ventures shell companies (T. Ewing and R. Feldman Stanford Technol. Law Rev. 1; 2012).

Intellectual Ventures, headquartered in Bellevue, Washington, chafes at the term patent troll. The company's global head of technology, Patrick Ennis, points to its role in launching three start-up companies, and to deals it has struck with Caltech and other universities to sponsor

"In the end, it just came down to money."

Universities often say that the goal of licensing patents is to stimulate the economy by translating publicly funded research into companies and products. But the unstated aim is to make money to fund more research and the technology-transfer office itself, says Melba Kurman, a former technology-transfer officer at Cornell University in Ithaca, New York, who now works as a consultant. The goals are sometimes in conflict. "If the goal is to monetize the patent portfolio, then it would make sense to auction it off to the highest bidder," says Kurman. "But when these patents cover taxpayer-funded research, that is not an acceptable solution."

Finding a bidder at all can be a coup for technology-transfer officers, who are often saddled with patents that are years away 
- from practical application. Joy Goswami, assistant director of the technology-transfer office at the University of Delaware in Newark, estimates that only about $5 \%$ of patents are licensed at most universities. The rest are a drain on office resources, he adds, because of required maintenance and legal fees.

Earlier this month, at a meeting of the Association of University Technology Managers in Boston, Massachusetts, Goswami led a discussion on how to unload the $95 \%$ of patents that remain unlicensed. One option is to use a broker or auction house that specializes in trading intellectual property. It is a controversial solution that some universities are afraid to touch. "When you go to sell a patent, the university loses any ability to ensure that it's being managed in the public's best interest," says Kelly Sexton, head of the technology-transfer office at North Carolina State University in Raleigh, which licenses out a relatively robust $15 \%$ of its patents.

Thomas Major, vice-president of IPOfferings, a patent-broker firm based in Boca Raton, Florida, does not understand the hesitation. He spent nine years managing intellectual property at the University of Utah in Salt Lake City, and says that universities would be foolhardy to ignore auction houses. "When I was at the University of Utah, I would have sold those patents in a heartbeat," he says.

Major says that IPOfferings has handled about 20 patents from universities over the past 3 years - roughly $7 \%$ of the firm's total business. James Malackowski, chief executive of Ocean Tomo in Chicago, Illinois, a company best known for its patent auctions, says that universities are increasingly coming to him, and represent nearly $20 \%$ of his business. Both Major and Malackowski say that their firms can place limits on who can buy or exclusively license a patent. Even so, Major says that at least one of his university clients abandoned that request after seeing how much a patent aggregator was willing to pay. "In the end, it just came down to money."

Such decisions violate the spirit of a 2007 memo endorsed by more than 100 institutions. Offering guidance for ethical patent licensing, it cites the risks of dealing with patent aggregators. Yet the signatories include Caltech and three other universities that have licensed patents to Intellectual Ventures, according to Feldman's research: Duke University in Durham, North Carolina; the University of Florida in Gainesville; and the University of Ottawa in Canada. The universities declined to comment on the patent deals.

Caltech mathematician Peter Schröder, one of the three inventors on US patent $7,023,435$, is not too bothered. He would be troubled, he says, if Intellectual Ventures were using his patent to harass other companies, but so far he has not heard of that happening. "It's not giving me heartache," he says. -

\section{Mozilla plan seeks to debug scientific code}

\section{BY ERIKA CHECK HAYDEN}

$\mathrm{W}$ hen ecologist Carl Boettiger wrote a blog post in June calling for greater stringency in the peer review of scientific software in research papers, he hardly expected to stir up controversy. But in 54 comments on the post, researchers have debated how detailed such reviews should be; one said that it was a "trifle arrogant" of Boettiger, of the University of California at Santa Cruz, to insist that computer code attain his stringent standards before publication.

Now an offshoot of the Internet non-profit organization Mozilla has entered the debate, aiming to discover whether a review process could improve the quality of researcher-built software that is used in myriad fields today, ranging from ecology and biology to social science. In an experiment being run by the Mozilla Science Lab, software engineers have reviewed selected pieces of code from published papers in computa-
"One worry is that scientists will be even more discouraged from publishing their code." tional biology. "Scientific code does not have that comprehensive, off-the-shelf nature that we want to be associated with the way science is published and presented, and this is our attempt to poke at that issue," says Mozilla Science Lab director Kaitlin Thaney.

Researchers increasingly rely on computation to perform tasks at every level of science, but most do not receive formal training in coding best practice. That has led to high-profile problems. Some scientists have argued, for example, that the fraudulent findings used as the basis for clinical trials in 2007 would have been exposed much earlier if cancer researcher Anil Potti of Duke University in Durham, North Carolina, had been compelled to publish his data and computer code along with his original papers.

More routinely, incorrect or slipshod code prevents other researchers from replicating work, and can even lead them astray. In 2006, Geoffrey Chang of the Scripps Research Institute in La Jolla, California, had to retract five research papers on crystal structure after finding a simple error in the code he was using, which had been provided by another lab. "That's the kind of thing that should freak any scientist out," says computational biologist Titus Brown at Michigan State University in East Lansing. "We don't have good processes in place to detect that kind of thing in software."

Mozilla is testing one potential process, deploying the type of code review that is routinely used on commercial software before it is released. Thaney says that the procedure is much like scientific peer review: "The reader looks for everything, from the equivalent of grammar and spelling to the correctness of the logic." In this case, Mozilla opted to examine nine papers from PLoS Computational Biology that were selected by the journal's editors in August. The reviewers looked at snippets of code up to 200 lines long that were included in the papers and written in widely used programming languages, such as R, Python and Perl.

The Mozilla engineers have discussed their findings with the papers' authors, who can now choose what, if anything, to do with the markups - including whether to permit disclosure of the results. Those findings will not affect the status of their publications, says Marian Petre, a computer scientist at the Open University in Milton Keynes, UK, who will debrief the reviewers and authors. Thaney expects to release a preliminary report on the project within the next few weeks.

Computational biologists are betting that the engineers will have found much to criticize in the scientific programming, but will also have learnt from the project. They may have been forced to brush up on their biology, lest they misunderstood the scientific objective of the code they were examining, Brown says.

Theo Bloom, editorial director for biology at non-profit publisher PLoS, shares that expectation, but says such reviews may still be useful, even if the Mozilla reviewers lack biological expertise. Yet that would prompt another question: how can journals conduct this type of review in a sustainable way?

The time and skill involved may justify paying reviewers, just as statistical reviewers of large clinical trials are paid. But researchers say that having software reviewers looking over their shoulder might backfire. "One worry I have is that, with reviews like this, scientists will be even more discouraged from publishing their code," says biostatistician Roger Peng at the Johns Hopkins Bloomberg School of Public Health in Baltimore, Maryland. "We need to get more code out there, not improve how it looks." - 